\title{
Shear resistance and continuity of subglacial till: hydrology rules
}

\author{
Neal R. IVERSON \\ Department of Geological and Atmospheric Sciences, lowa State University, 253 Science 1, Ames, lowa 50011, USA \\ E-mail: niverson@iastate.edu
}

\begin{abstract}
The field observations of G.S. Boulton stimulated widespread interest in deformable beds. Shear resistance of till in its critical state is insensitive to strain rate and increases linearly with effective pressure. During unsteady deformation, pseudo-viscous shear resistance can be caused by dilation of consolidated tills and resultant pore-pressure decline. This effect is probably uncommon, however, because susceptible tills of low hydraulic diffusivity are also those least likely to consolidate significantly during effective-pressure transients. Stick-slip motion at Whillans Ice Stream, Antarctica, indicates that its basal till must weaken during rapid slip and strengthen during longer periods of slower slip. Recurrence intervals for rapid-slip episodes there (6-18 hours) indicate that till-strength variations, if driven by changes in pore pressure either related or unrelated to basal freezing, are focused in the uppermost several centimeters of the bed. Ploughing of grains at the bed surface and associated excess pore pressures in adjacent till can account for rate-weakening during rapid slip, with pore-pressure decay causing strengthening between slip episodes. By promoting shallow, sluggish subglacial water flow and low effective pressure, soft beds may help sustain themselves by slowing their own transport. Soft-bed shear resistance, kinematics and continuity are problems rooted in subglacial hydrology.
\end{abstract}

\section{INTRODUCTION}

In 1978 the Royal Society of Canada and Ottawa University co-sponsored a meeting on glacier-bed processes, with proceedings that were published a year later as the 89th issue of the Journal of Glaciology. Papers on hard-bedded sliding (e.g. Fowler, 1979; Lliboutry, 1979; Weertman, 1979) and related geomorphic (e.g. Hallet, 1979) and hydrological (e.g. Hodge, 1979) processes dominated the proceedings. Only one contribution emphasized deformable beds: a review paper by Boulton (1979) that included measurements of bed deformation beneath Breiðamerkurjökull, Iceland. In a published discussion comment following this article, J. Weertman proclaimed deformable beds to be a 'new, major field of research'.

Weertman's comment was prescient. Less than a decade later at a Chapman conference on fast glacier flow (Clarke, 1987a), attention had shifted primarily to soft glacier beds. Interest by glaciologists, however, was tardy (Boulton, 1986). Eighty-four years earlier, W.J. McGee, while pondering resistance to glacier slip, had considered the possibility of 'differentially-moving ground moraine' beneath glaciers that would 'diminish friction' (McGee, 1894). Many subsequent glacial geologists made observations that indicated ice sheets and glaciers sometimes deformed their unlithified beds (Slater, 1926; Dyson, 1952; Hoppe, 1952; MacClintock and Dreimanis 1964; Moran, 1971). The slowness of glaciologists to seriously explore the deformable-bed concept probably, in part, reflects their long-term observations at the time on mountain glaciers, where soft beds are less common than beneath lowland glaciers. In addition, there may have been intellectual bias: experts on the flow and thermodynamics of ice were perhaps predisposed to not muddy the sliding problem with dirt.

No single researcher helped bring deformable beds to the attention of glaciologists more effectively than G.S. Boulton. In 1970, as benchmark papers on hard-bedded sliding were published (Kamb, 1970; Nye, 1970), two companion papers by Boulton appeared in the Journal of Glaciology that discussed observations of sediments within and under several glaciers in Svalbard (Boulton, 1970a,b). These observations included foliations and fabrics in subglacial till that indicated it had been sheared. Notably, he was skeptical that the high pore-water pressures that were necessary to enable such deformation could be sustained over wide areas of the bed and concluded that 'subglacial shearing-along of masses of till, as proposed by some authors, seems to be unrealistic'.

A few years later, observations of the porous upper layer of till beneath Breiðamerkurjökull had changed his mind (Boulton and Dent, 1974; Boulton and others, 1974; Boulton, 1975; Boulton and Paul, 1976). He suggested that bed deformation might be widespread beneath some glaciers and potentially responsible for surging (Boulton and others, 1974) and the formation of drumlins (Boulton and others, 1974) and flutes (Boulton, 1976). By 1979 he had made his famous direct measurements of shear deformation in the till beneath Breiðamerkurjökull (Boulton, 1979). In a second paper in the Journal of Glaciology that year, a case was made for subglacial sediment having been sufficiently widespread and weakened by high pore-water pressures to have been responsible for the seemingly unstable and anomalously gently-sloping margins of some Pleistocene ice sheets (Boulton and Jones, 1979). The authors conceded, however, that this explanation did not seem to agree with observations of modern ice sheets, leading to the 'uncomfortable implication that large Pleistocene ice sheets behaved differently from modern ones'.

This discomfort was relieved by the discovery of thick, unlithified sediments beneath the fast-moving and very gently sloping Whillans Ice Stream (WIS; formerly Ice Stream B), Antarctica, and with the recognition that these sediments were porous and potentially deforming (Alley and others, 1986; Blankenship and others, 1986). Boulton's observations from the 1970s were now clearly relevant to the dynamics of modern ice sheets. Field efforts to study deformable beds were initiated beneath ice streams (Engelhardt and others, 1990) and surge-type glaciers (Blake and 
others, 1992). Theoreticians began to address bed deformation explicitly (Alley and others, 1987; Boulton and Hindmarsh, 1987; Clarke, 1987b; Alley, 1989) and include it in large-scale models of glacier flow (e.g. MacAyeal, 1989, 1992). The glacial stratigraphic record and various landforms were reinterpreted from the standpoint of bed deformation (e.g. Alley, 1991), as was accumulating evidence indicating that the margins of Pleistocene ice sheets were indeed thin and volatile (e.g. Clark, 1992, 1994). Laboratory experiments began to be conducted to explore till mechanical properties (Kamb, 1991). In the Journal of Glaciology, Boulton (1996) presented a model of erosion, transport and deposition by a soft-bedded ice sheet, assuming that bed deformation was the only mode of sediment transport and fully responsible for basal motion. The pendulum had swung toward deformable beds.

The goal of this review is to address two of the central questions that have emerged from research on bed deformation since the mid-1980s. What factors govern till shear resistance, and how are soft beds sustained, despite their vulnerability to transport and their tendency to shield from erosion the bedrock that nourishes them? The former issue has been contentious. Considerable study, however, has answered some important questions, while remarkable field observations (e.g. Bindschadler and others, 2003) have posed new ones. In comparison the problem of till continuity is probably more fundamental (Alley, 2000) but far more ill-constrained, with treatments, including this one, that tend to be brief, qualitative, and hampered by lack of long-term data on subglacial sediment transport. A comprehensive review of deformable beds can be found in Cuffey and Paterson (2010), which builds on Clarke's (2005) review of subglacial processes. Other valuable reviews, with diverse perspectives, have been provided by Murray (1997), Alley (2000) and Hooke (2005).

\section{TILL SHEAR RESISTANCE}

Difficult and usually frustrating efforts to instrument subglacial sediments of modern glaciers through boreholes indicate that these sediments deform, at least sporadically (see Cuffey and Paterson, 2010, table 7.4, for citations). These measurements necessarily sample a minute fraction of glacier beds and usually are of limited duration (a few days to several months). However, in sediments uncovered by past glaciers, folds, faults and strongly aligned grains reinforce the conclusion that glacier beds commonly deform. Moreover, the very low surface slopes of modern ice streams, with till beds that are known to be extensive and weak, leave little doubt that low shear resistance of soft beds can profoundly affect glacier dynamics.

\section{Critical-state strength of till}

Boulton and Jones (1979) characterized the steady shear strength of till - its ultimate strength - with the Coulomb failure criterion, as modified by Terzaghi (1943) to include the effect of pore pressure on intergranular friction: $\tau_{\mathrm{u}}=$ $c+p_{\mathrm{e}} \tan \phi$, where $c$ is till cohesion, $\phi$ is the till friction angle and $p_{\mathrm{e}}$ is the effective pressure (pore pressure minus overburden pressure of ice and wet sediment). This characterization of till strength is awkward for those seeking to construct models for either the flow of geometrically simple glaciers by bed deformation or the development of subglacial landforms. Till shear-strain rate and hence glacier

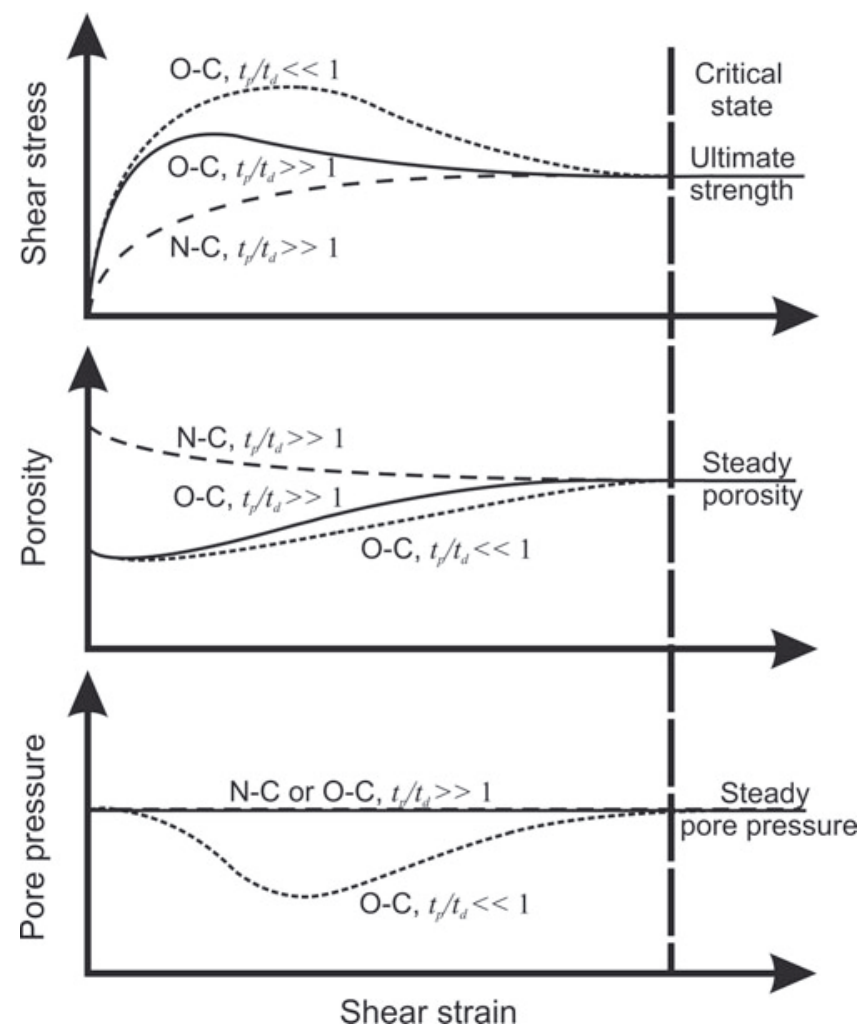

Fig. 1. Shear stress, porosity and pore pressure during deformation of tills that are normally consolidated $(\mathrm{N}-\mathrm{C})$ and overconsolidated (O-C), with different drainage conditions defined by $t_{\mathrm{p}} / t_{\mathrm{d}}$, where $t_{\mathrm{p}}$ and $t_{\mathrm{d}}$ are characteristic timescales of pore dilation and porepressure diffusion, respectively.

flow velocity are indeterminate. Moreover, Coulomb deformation implies that quasi-static stress equilibrium could be readily violated during flow of a glacier resisted only by its deforming till bed. In that case, small uniform increases in either driving stress, $\tau_{\mathrm{D}}$, or pore-water pressure could yield $\tau_{\mathrm{D}}>\tau_{\mathrm{u}}$ and catastrophic glacier acceleration.

This awkwardness helped inspire power-law flow rules for till of the general form, $\dot{\varepsilon}=A \tau^{n}$, where $\dot{\varepsilon}$ is strain rate, $\tau$ is shear stress in excess of a specified yield stress (assumed to be zero in some cases), and $A$ and $n$ are constants. $A$ is usually taken to depend inversely on effective pressure (e.g. Boulton and Hindmarsh, 1987; Alley, 1989). This viscoplastic rheology for till is convenient for modeling both glacier flow on deformable beds and the development of subglacial landforms.

Critical-state soil behavior (e.g. Schofield and Wroth, 1968; Wood, 1990) provides a rational starting point for assessing till rheology (Clarke, 1987b; Kamb, 1991; Tulaczyk and others, 2000a) and the physical relevance of viscoplastic flow rules. If sheared to a sufficient strain (usually $\ll 1.0$ Lambe and Whitman, 1969) under a particular ambient effective pressure, till will attain a critical state in which porosity and shear resistance remain steady with further strain (Fig. 1). For a particular granular material, this shear resistance - the ultimate strength - can be uniquely determined by knowing either effective pressure or water content, a surrogate for porosity or void ratio if till is watersaturated (e.g. Tulaczyk and others, 2000b; Clarke, 2005).

At lower strains, shear resistance is more complicated. Porosity changes associated with grain rearrangement during shear stimulate changes in internal friction and commonly 

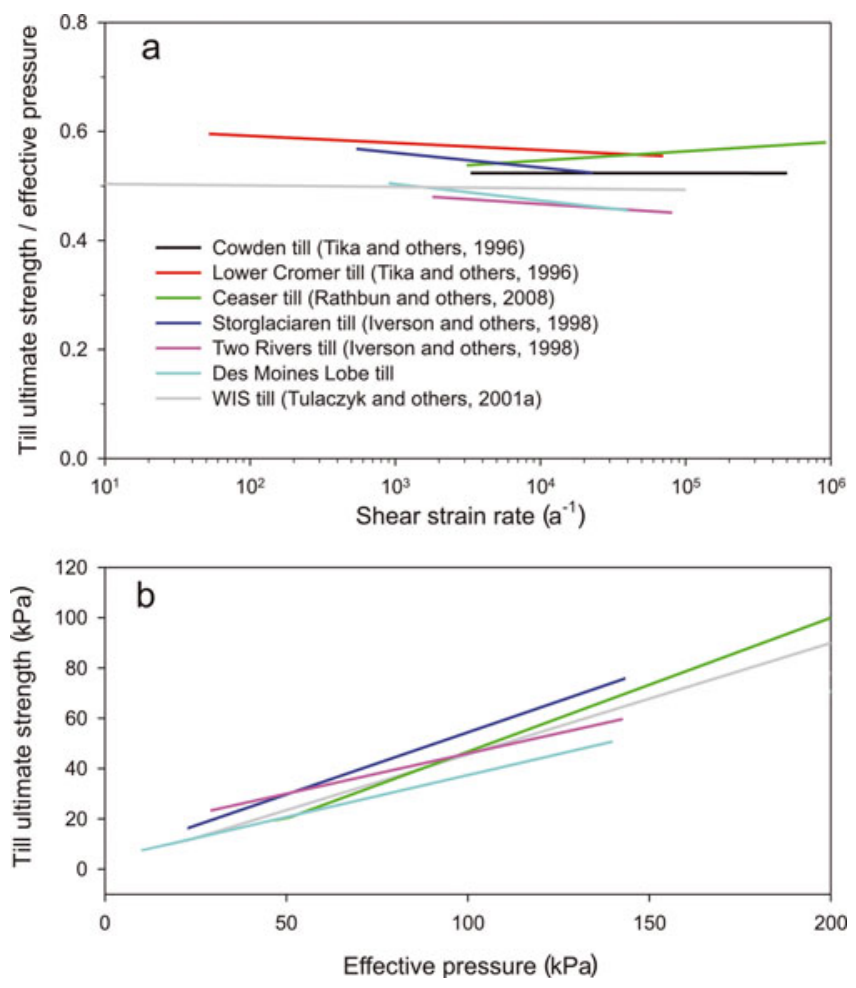

Fig. 2. (a) Till ultimate strength normalized by effective pressure, as a function of shear strain rate, from regressions of laboratory data for seven tills. Shear strain rates from ring-shear experiments were calculated by dividing shear rate by a measured (Iverson and others, 1998) or estimated (Tika and others, 1996) shear-zone thickness. (b) Till ultimate strength as a function of effective pressure for five of the seven tills in (a). Tests on the Cowden till and Lower Cromer till were conducted at an insufficient number of effective pressures to obtain a relationship.

pore-water pressure that lead to stress-strain behavior dependent on initial porosity (Fig. 1). Thus, if basal till is perturbed by smaller strains than those required of the critical state, such as by propagation of microearthquake waves (Anandakrishnan and Alley, 1997), flow-law interpretations (e.g. Alley, 2000) are inherently more difficult. Some rheological models can accommodate both transient deformation and deformation in the critical state. For example, the Disturbed-State model of Sane and others (2008) describes the transition from a 'relative-intact' state to a 'fully-adjusted' state, in which material microstructure reaches a dynamic steady state comparable to the critical state. The model uses a disturbance function that describes the fraction of the till mass that evolves from the intact to the adjusted state as strain accrues. Sane and others (2008; see their figs 9 and 10) demonstrate that their model, which carries the liability of requiring measurement or estimation of 16 material parameters, can accurately predict till stressstrain behavior up to strains of 0.4 , sufficient to be near or at the critical state.

Data from laboratory experiments conducted to comparable or larger strains provide the least uncertain assessment of controls on critical-state till shear resistance (Clarke, 2005), which is most relevant to large strains expected subglacially (Kamb, 1991). Despite being conducted with diverse soil-deformation devices (triaxial, ring-shear and double-direct shear), these experiments uniformly indicate that till ultimate strength is highly insensitive to strain rate
(Fig. 2a). Ultimate strength, normalized by effective pressure, tends to mildly increase or decrease linearly with the logarithm of strain rate or be essentially independent of it. In cases in which till strengthens with strain rate, fitted values of $n$ are very large $(n \sim 75$ (Kamb, 1991), $n>60$ (Rathbun and others, 2008)), indicating essentially plastic behavior.

The need to invoke such large $n$ values, as well as the rate-weakening tendency of some tills, indicates that powerlaw rules predicated on fluid rheological behavior of till poorly characterize steady-state till deformation. It follows that till effective viscosity cannot be measured or estimated meaningfully, despite efforts to simplify conditions in the laboratory. Therefore, models that invoke till viscosity, either to calculate it from field measurements (see reviews by Murray, 1997; Cuffey and Paterson, 2010) or to use it as a foundation for hypothesis testing, are of a class criticized as 'floating models' (Savage, 1998; Iverson, 2003). Such models are moored to parameters that are not measurable outside the context of the model formulation and hence have uncertain physical relevance.

In contrast, Coulomb behavior, as indicated by a linear dependence of till ultimate strength on effective pressure, is well supported by these same experimental studies (Fig. 2b). Internal friction angles in the critical state are $17-28^{\circ}$. Ultimate strength is roughly two orders of magnitude more sensitive to effective pressure than to strain rate.

Thus, laboratory experiments indicate that Coulomb plasticity is a good idealization for tills (Clarke, 2005; Cuffey and Paterson, 2010). With the exception of the study of Boulton and Hindmarsh (1987), for which methodological questions have been raised (Hooke and others, 1997), field measurements generally reinforce this viewpoint (Hooke and others, 1997; Truffer and others, 2001; Kavanaugh and Clarke, 2006; Tulaczyk, 2006). An important implication is that driving stress can exceed the ultimate strength of till if it is weakened sufficiently by high pore-water pressure. Thus, sources of viscous deformation resistance must be active for stable flow of soft-bedded glaciers. In the case of ice streams, their margins (Whillans and Van der Veen 1997; Tulaczyk and others, 2000b; Raymond and others, 2001), sticky spots (Alley, 1993; MacAyeal and others, 1995; Stokes and others, 2007) and ice shelves (e.g. Price and others, 2002) help provide the necessary resistance.

\section{Pseudo-viscous creep?}

Although the critical state is the appropriate reference state for characterizing the shear resistance of subglacial till, it will not always be at its critical-state porosity and strength. On the one hand, if bed deformation contributes significantly to glacier flow and sediment transport, till should commonly be deformed sufficiently to attain the relatively small strains required of the critical state. On the other hand, effective pressure is not steady subglacially - even beneath some ice streams with no surface water input to the bed (Engelhardt and Kamb, 1997) - and this variability can result in episodic bed deformation (Blake and others, 1994; Iverson and others, 1995, 1999, 2007; Fischer and Clarke, 1997; Truffer and Harrison, 2006). If, for example, effective pressure increases and then decreases on a till initially at its critical state porosity, the till will consolidate and then swell; swelling, however, will typically be only a small fraction $(\sim 0.2)$ of consolidation because grain rearrangement during consolidation is largely irreversible (e.g. Clarke, 1987b, 2005). The till will thus be left less porous than in the critical 


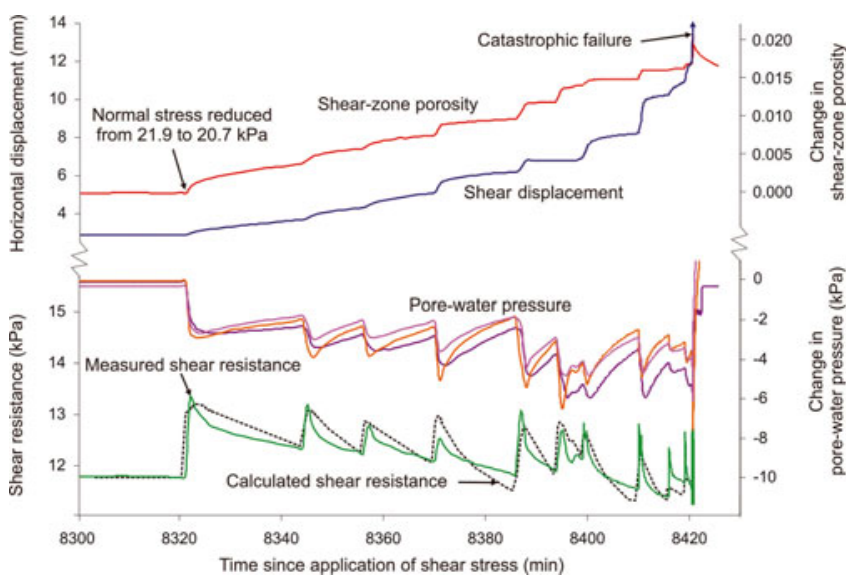

Fig. 3. Data from a ring-shear experiment on the Storglaciären basal till illustrating dilatant strengthening. A constant shear stress was applied to the till, and total normal stress was reduced in small increments until the till began to shear. Pore-water pressure was measured at three locations along the till-specimen center line and within the shear zone (17 mm thick). Shear resistance was measured and also calculated with the average pore pressure, total normal stress, and Coulomb friction rule. Cohesion was assumed to be negligible, based on past experiments with this till (Iverson and others, 1998), and friction angle was assumed to decrease linearly with porosity (Lambe and Whitman, 1969) as pores dilated progressively during shear (from Moore and Iverson, 2002). Reproduced from Geology with permission of the Geological Society of America.

state and potentially subject to strengthening during the early stages of a subsequent deformation event (Fig. 1). Alley (2000) and Fowler (2003) argued on that basis that many deformation events could yield time-averaged pseudoviscous behavior. The Sane and others (2008) model, with parameters specified appropriately, could also likely yield pseudo-viscous behavior.

A particularly potent transient strengthening mechanism that has been long appreciated (Reynolds, 1885) and commonly invoked in fault mechanics (e.g. Segall and others, 2010) involves pore-pressure reduction caused by dilation during the early stages of till shear (Clarke, 1987b; Iverson and others, 1998). Data from a ring-shear experiment on a water-saturated till in communication with an external water reservoir illustrate the process (Fig. 3) (Moore and Iverson, 2002). A constant shear stress was applied to an overconsolidated till, and effective pressure was incrementally reduced until creep was instigated (minute 8323, Fig. 3). The associated rate of dilation outpaced porepressure diffusion into the opening void space, causing an abrupt pore-pressure reduction that reduced rates of shear and dilation with continued shear displacement. As these rates decreased, pore pressure slowly recovered until sufficient to instigate another shear event that was again stabilized by dilation and consequent pore-pressure reduction. A total of ten slip episodes occurred before the till reached its critical-state porosity and hence was unable to dilate further. As a result, shear accelerated, and the till failed catastrophically. In similar experiments on dry till, there were no episodic slip events (Moore, 2002).

These experiments illustrate a transitional state - germane to subglacial tills - between the end-member 'drained' and 'undrained' states of geotechnical engineering, which correspond to unsealed and sealed laboratory test cells (e.g. Clarke,

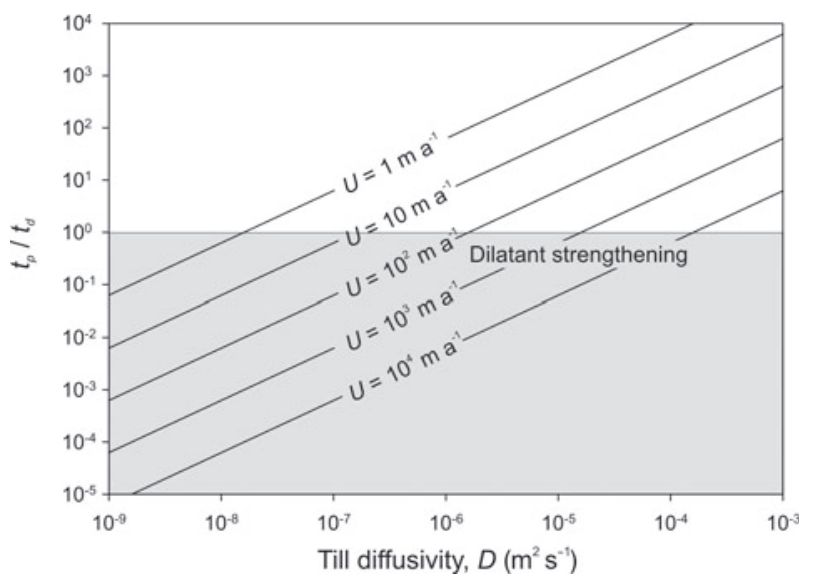

Fig. 4. Values of $t_{\mathrm{p}} / t_{\mathrm{d}}$ plotted as a function of hydraulic diffusivity for various sliding speeds, $U$, assuming all basal motion is by bed deformation, a shear-zone thickness of $0.5 \mathrm{~m}$, and $\Delta n / \psi=1$. Values of $t_{\mathrm{p}} / t_{\mathrm{d}}$ less than unity (shaded) indicate partially undrained conditions and dilatant strengthening.

2005). Subglacial tills do not reside in sealed containers but can diffuse pore pressure sufficiently slowly as porosity changes to cause non-hydrostatic pore pressures. The characteristic timescale for pore-pressure diffusion is $t_{\mathrm{d}}=$ $H^{2} / D$, where $D$ is the hydraulic diffusivity and $H$ is the characteristic diffusion length, equal to the shear-zone thickness. The characteristic timescale for porosity change is $t_{\mathrm{p}}=H \Delta n / \psi U$, where $\Delta n$ is the porosity change required to reach the critical-state porosity during the early stages of shear, $\psi$ is the ratio of shear-zone thickness change to shear displacement, which approaches zero as the critical state is approached, and $U$ is the sliding speed, assuming all basal motion is by bed deformation. If the ratio of these two timescales, $t_{\mathrm{p}} / t_{\mathrm{d}}=\Delta n D / U \psi H$, is much less than unity, significant pore-pressure reduction during dilation is expected (Fig. 1); $t_{\mathrm{p}} / t_{\mathrm{d}} \rightarrow \infty$ and $t_{\mathrm{p}} / t_{\mathrm{d}} \rightarrow 0$ correspond to the drained and undrained end-members (Iverson and others, 1997).

For much of the relevant ranges of till hydraulic diffusivity $\left(10^{-9}-10^{-3} \mathrm{~m}^{2} \mathrm{~s}^{-1}\right.$; Cuffey and Paterson, 2010) and sliding speed, dilatant strengthening is expected (Fig. 4). However, this conclusion applies only if till is less porous than in the critical state, owing to consolidation. This consolidation also requires pore-pressure diffusion with the characteristic timescale, $t_{\mathrm{d}}$. Thus, tills that are least diffusive and hence most susceptible to dilatant strengthening (Fig. 4) are also those that reduce their porosities most slowly in response to an increase in effective pressure. These tills will be least likely to develop a porosity that departs widely from the critical-state value. The implication is that for dilatant strengthening to operate subglacially, periods with till under elevated effective pressure may need to be long (e.g. $t_{\mathrm{d}}=29$ days for $D=10^{-7} \mathrm{~m}^{2} \mathrm{~s}^{-1}$ and $H=0.5 \mathrm{~m}$ ) relative to periods of active shear to induce consolidation sufficient for subsequent dilation during shear. This conclusion is reinforced by the observation that tills that are only weakly overconsolidated dilate insignificantly during shear (Tulaczyk and others, 2000a).

Thus, pseudo-viscous response to unsteady deformation is probably the exception, rather than the rule, beneath glaciers. Even if the process does commonly operate, the associated strength variability with shear rate is likely subtle relative to till strength set by the ambient state of effective 

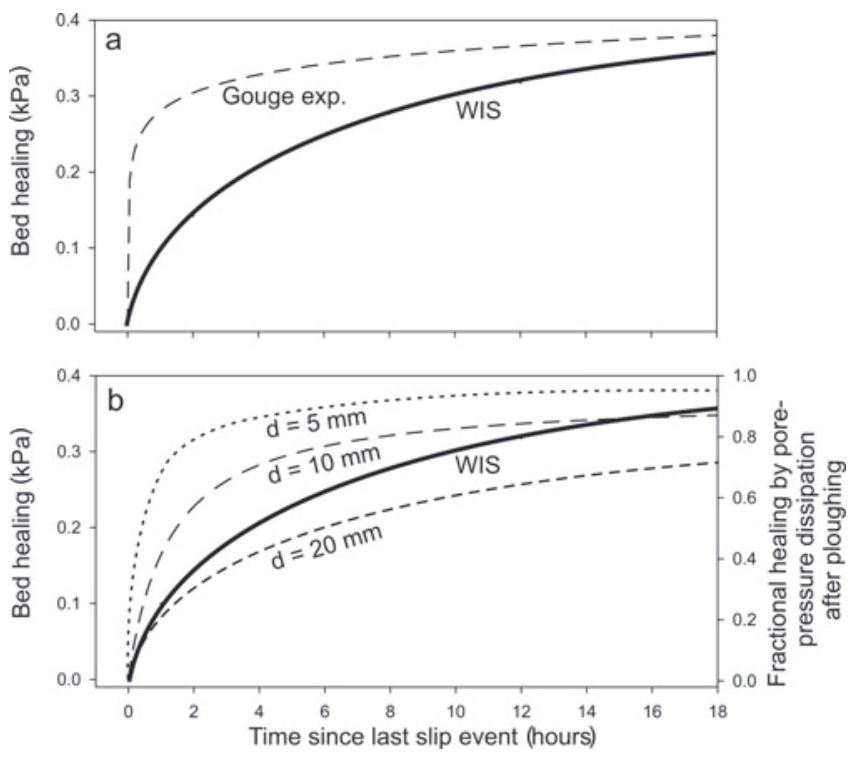

Fig. 5. Bed healing during the period following a slip event at WIS (Winberry and others, 2009) compared with (a) that expected from healing of a simulated fault gouge (Marone, 1998b) and (b) fractional healing of till by pore-pressure dissipation at the surfaces of particles with diameters of 5, 10 and $20 \mathrm{~mm}$, after they have ploughed through the WIS till $\left(D=10^{-8} \mathrm{~m}^{2} \mathrm{~s}^{-1}\right)$. Fractional healing was calculated from the theory of Randolph and Wroth (1979), which assumes plane strain adjacent to an expanding cylindrical cavity in an ideally elastic, perfectly plastic soil. A key parameter in their model is the ratio of soil shear modulus to undrained shear strength, assumed herein to be 50, appropriate for soft clay-rich sediment (Randolph and Wroth, 1979), such as the WIS till.

pressure and its temporal and spatial variations (Alley, 2000). Spatial gradients in pore-water pressure may be large, given that glacial-sediment permeability (till, outwash sand and gravel) can vary through $\sim 12$ orders of magnitude (Freeze and Cherry, 1979). Well-drained zones of anomalously high effective pressure and strength, a candidate for sticky spots (Stokes and others, 2007), may be common.

\section{Slick-slip motion: Whillans Ice Stream}

Definitive inferences regarding till mechanical properties from large-scale observations of glacier flow are inherently difficult. Shear stresses driving bed deformation are always poorly known due to other sources of drag, including sticky spots and ice margins. In addition, the degree of till continuity at the bed is usually uncertain, with usually little or no knowledge of bed-deformation kinematics.

Some of these problems are minimized beneath the mouth of WIS, where till is thought to be thick and sticky spots rare, and where widening of the ice stream leaves drag exerted by its margins very distant from most of the bed (Bindschadler and others, 2003). There the ice stream exhibits dramatic stick-slip motion: rapid displacements of $\sim 0.5 \mathrm{~m}$ that occur once or twice a day over periods of $<30 \mathrm{~min}$, with intervening long periods of much slower flow (6-18 hours; Winberry and others, 2009). Although GPS data are, to date, insufficient to precisely determine ice speeds during rapid-slip episodes, increases in speed of approximately two orders of magnitude are indicated (Sergienko and others, 2009). Rapid-slip episodes cause far-field seismicity and nucleate at a sticky spot associated with Ice Rise A (Wiens and others, 2008). They are driven by accumulation of elastic strain in the ice during slow-slip periods and tidal oscillations of only $\sim 1 \mathrm{~m}$ (Bindschadler and others, 2003; Sergienko and others, 2009). Shear-stress reductions during rapid slip are $\sim 0.20-0.35 \mathrm{kPa}$ (Winberry and others, 2009).

This stick-slip motion reveals aspects of the mechanical behavior of the basal till there. The observed extreme sensitivity of slip velocity to small changes in stress indicates that the till does not strengthen with increasing strain rate (Bindschadler, and others, 2003; Tulaczyk, 2006). This conclusion agrees with results of laboratory experiments on basal tills, including the till collected upstream from beneath WIS (Fig. 2a), and casts doubt on the contention of Hindmarsh (1997) that small-scale plastic behavior yields a pseudo-viscous till flow rule at large scales (Tulaczyk, 2006).

However, to enable stick-slip, two other criteria must be met by the till. As the ice stream transitions from slow to fast sliding, purely plastic till behavior is insufficient. Rather, slip resistance must decrease with increasing slip rate, such that there is so-called rate-weakening (Thomason and Iverson, 2008; Winberry and others, 2009), sometimes idealized as a decrease from static to dynamic friction (Sergienko and others, 2009). As elastic strain in the loading system - in this case in the ice - is released during rapid slip, rate-weakening must be sufficiently large for slip resistance to decrease more rapidly with displacement than the shear stress applied by the ice (Scholz, 2002). The resultant force imbalance causes slip acceleration. Slip is halted only sometime after the force balance is restored by elastic relaxation of ice. The second criterion for stick-slip is that till strength lost during rapid slip must be recovered during intervening periods. This 'healing' is well documented in fault rocks and gouge (Marone, 1998b), a granular material texturally similar to till. Winberry and others (2009) noted that at WIS the rate of healing (strength increase) must decrease with time to explain relationships between durations of slow-slip periods and amplitudes and signs of tidal forcing (Fig. 5).

\section{Rate-weakening and healing data}

Laboratory tests on the fine-grained WIS till (35\% clay-sized particles) indicate no significant tendency for it to weaken with increasing strain rate (Fig. 2a) (Tulaczyk and others, 2000a), inconsistent with stick-slip. The till studied, however, was collected $>200 \mathrm{~km}$ upstream of where stick-slip is observed. Lithologic and textural changes of deglaciated basal tills are common over similar distances (e.g. Clark, 1987). A relevant question, therefore, is whether other finegrained tills display the requisite degree of rate-weakening. Two of these are the Two Rivers (32\% clay-sized particles) and Des Moines Lobe (16\% clay-sized particles) tills. These tills have critical-state friction coefficients, $\mu=\tan \phi$, that decrease 0.018 and 0.025 , respectively, per order-ofmagnitude increase in deformation rate (Fig. 2a). If the till beneath WIS weakens similarly with increasing slip velocity, the slip-velocity increase of a factor of $\sim 100$ during stickslip transitions at WIS would result in stress reductions of 0.32 and $0.45 \mathrm{kPa}$, assuming $P_{\mathrm{e}}=9 \mathrm{kPa}$ (based on a till yield stress of $4 \mathrm{kPa}$ (Kamb, 2001) and a friction angle for the WIS till of $24^{\circ}$ (Tulaczyk and others, 2000a)). These values are similar to the maximum inferred stress reduction at WIS. Thus, a till with a different texture from the one studied upstream of the location of the stick-slip episodes could satisfy the rate-weakening criterion.

Although there are no data that directly bear on healing of tills, there are healing data from slide-hold-slide tests on 
fault gouge (e.g. Marone and Kilgore, 1993; Marone, 1998a,b). These data indicate static friction coefficients increase with the logarithm of time between slip episodes, with increases in some cases of $\sim 0.04$ over periods of $1 \mathrm{~s}$ to 18 hours. This increase in friction would result in healing of approximately $0.39 \mathrm{kPa}$ over an 18 hour period at WIS (Fig. 5a), with rate of healing decreasing with time there, as inferred by Winberry and others (2009) (Fig. 5).

Although some tills rate-weaken sufficiently to explain modeled stress reductions at WIS and some fault gouge heals sufficiently quickly to restore strength losses over measured recurrence intervals there, the applicability of these observations to stick-slip at WIS is uncertain. In experiments with fault gouge, effective pressures are orders of magnitude higher than at WIS. Perhaps more importantly, slip during quiescent periods at WIS $\left(\sim 90 \mathrm{~m} \mathrm{a}^{-1}\right.$; Sergienko and others, 2009) likely inhibits healing at rates observed during static periods of slide-hold-slide experiments, just as post-earthquake slip on crustal faults inhibits their healing (e.g. Marone, 1998a). An additional uncertainty stems from the observation that healing in gouge is accompanied by consolidation, and rapid shear is accompanied by dilation (Marone and Kilgore, 1993; Marone, 1998a). Similarly, if healing of till is accompanied by sufficient consolidation, the till will dilate during the early stages of rapid slip. The WIS till is hydraulically tight $\left(D=10^{-8} \mathrm{~m}^{2} \mathrm{~s}^{-1}\right.$; Tulaczyk and others, 2000a), so its dilation could cause pore-pressure reduction that would strengthen it with increasing shear rate, rather than weaken it (Fig. 4). Slide-hold-slide tests on till, particularly on the WIS till, would clearly be valuable. Without more experimental data on tills, however, other hypotheses for stick-slip merit consideration.

\section{Alternative mechanisms for rate-weakening and healing}

The lack of rate-weakening displayed by the WIS till in experiments helped prompt Winberry and others (2009) to suggest that the time-dependent strength of the till bed at WIS is regulated by basal freezing (e.g. Joughin and others, 2004). Healing during periods between rapid-slip episodes was attributed to dewatering of till by basal freezing (Tulaczyk and others, 2000b; Christoffersen and Tulaczyk, 2003), which would be accompanied by consolidation. Rate-weakening during rapid slip was attributed to till dilation and the production of water by basal melting.

To account for the short recurrence intervals of rapid-slip episodes at WIS, rate-weakening and healing by any porewater driven mechanism must be focused in only a thin layer at the bed surface, owing to the low hydraulic diffusivity of the WIS till. Consider healing caused by suction during basal freezing. Taking $D=10^{-8} \mathrm{~m}^{2} \mathrm{~s}^{-1}$ (Tulaczyk and others, 2000a) yields penetration of the pore-pressure perturbation to a characteristic depth, $T=(D t)^{1 / 2}$, where $t$ is the time since a slip event. If $t<1$ day, then $T<30 \mathrm{~mm}$. Thus, for this healing mechanism to control basal slip resistance, till at greater depths must be steadily stronger (e.g. frozen) and hence rigid. Problematically, dilation of the consolidated uppermost few centimeters of the bed during rapid slip would cause pore-pressure reduction and strengthening, rather than weakening, of the WIS till (Fig. 4). Pore-pressure reduction might indeed be counteracted by production of meltwater during rapid slip to help bring about the necessary rate-weakening, but the effect of meltwater on till pore pressure would be limited to $\sim 4 \mathrm{~mm}$ of the uppermost part of the bed during brief ( $<0.5$ hour) episodes of rapid slip, significantly thinner than the thickness of till strengthened between rapid-slip episodes by basal freezing.

A style of bed deformation that inherently involves only the uppermost part of a till bed - ploughing (Brown and others, 1987; Alley, 1989; Iverson, 1999; Tulaczyk, 1999; Iverson and others, 2007) - provides another potential mechanism for time-dependent slip resistance at WIS. A glacier is coupled to its soft bed by till clasts that protrude from the bed partway into the glacier sole (e.g. Boulton, 1975; Brown and others, 1987; Alley, 1989). A water layer separates the bed from the glacier, and even if this layer is thin (e.g. $~ 0.1 \mathrm{~mm}$; Engelhardt and Kamb, 1997), most of the bed area is submerged in the layer because fine sand, silt and clay constitute the bulk of most tills. Local bed shear stresses are thus focused only on larger isolated particles that span the water layer. If the till bed is weakened sufficiently by low effective pressure, these isolated particles will plough down-glacier through the bed surface under shear stresses insufficient to cause either significant sliding by regelation or pervasive bed deformation at depth. Observations at many glaciers, including WIS, indicate bed-deformation kinematics consistent with ploughing: deformation occurs near the bed surface $(<0.1 \mathrm{~m})$ if effective pressure is falling or particularly low (Trapridge Glacier, Canada (Fischer and Clarke, 1997); Storglaciären, Sweden (Iverson and others, 1999); WIS (Engelhardt and Kamb, 1998); Breiðamerkurjökull (Boulton and others, 2001); Engabreen, Norway (Iverson and others, 2007)). Measurements by Truffer and Harrison (2006) at Black Rapids Glacier, Alaska, also indicate deformation focused near the bed surface $(<0.2 \mathrm{~m})$. In addition, there is clear evidence of ploughing in the geologic record (Westgate, 1968; Ehlers and Stephan, 1979; Shaw, 1982, 1987; Clark and Hansel, 1989).

Potential rate-weakening and healing associated with ploughing is illustrated by a well-studied practice in geotechnical engineering: pile driving. As a pile is driven into water-saturated, fine-grained sediment, it penetrates the sediment more easily than indicated by its drained strength; rapid movement of the pile causes compaction adjacent to it that outpaces pore-pressure diffusion, thereby generating excess pore pressures and weakening the sediment. After a pile is emplaced, it is left unloaded for hours to weeks until excess pore pressures adjacent to it have decayed and the sediment strength has increased to near its ambient value. Excess pore pressures and the characteristic period of their subsequent decay increase with the pile diameter (e.g. Randolph and Wroth, 1979).

Ploughing physics at WIS may be similar. Rapid slip by ploughing may cause excess pore pressures and weakening of till adjacent to ploughing particles, reducing overall slip resistance as slip velocity increases. Pore-pressure decay and associated till strengthening during periods of either much slower slip or switch to movement by bed deformation at depth would provide the necessary healing. Experiments in which different-sized hemispheres were dragged through tills at various speeds indicate reductions in ploughing resistance by factors up to $\sim 6$ with a six-fold increase in ploughing speed (Fig. 6a) (Thomason and Iverson, 2008). This weakening is in order-of-magnitude agreement with predictions of cavity-expansion theory applied to pile driving (e.g. Carter and others, 1979; Randolph and Wroth, 1979) and far greater than rate-weakening displayed by any till during shear (Fig. 2a). Reductions in ploughing resistance 

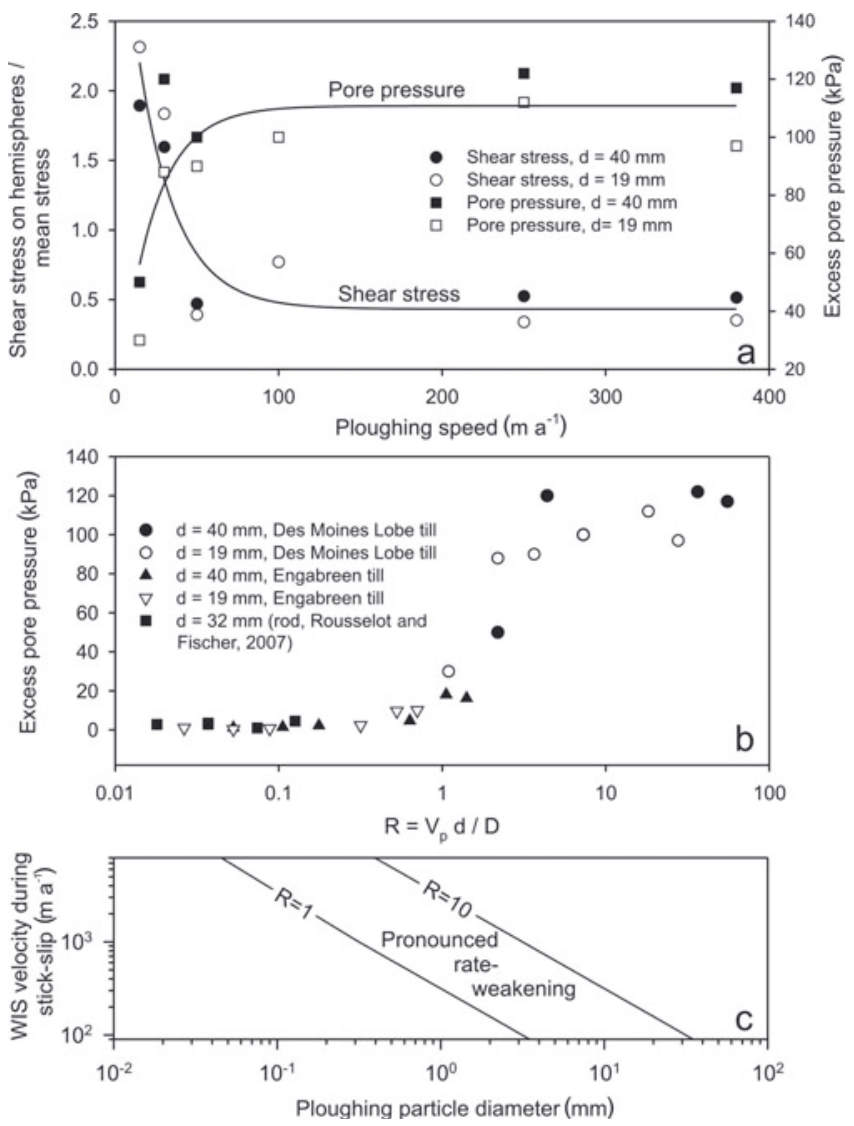

Fig. 6. (a) Steady shear stresses, normalized to their mean value, on hemispheres of two sizes $(d=19$ and $40 \mathrm{~mm})$ as they ploughed through the basal till of the Des Moines Lobe $\left(D=8.7 \times 10^{-9} \mathrm{~m}^{2} \mathrm{~s}^{-1}\right)$ at various steady speeds in ring-shear experiments. Also plotted are pore pressures in excess of hydrostatic measured about one radius 'down-glacier' from the hemispheres. (b) Excess pore pressures plotted as a function of $R$ from ploughing experiments conducted at various ploughing speeds, with tills of different hydraulic diffusivity and with ploughing tools of different sizes. All data are from Thomason and Iverson (2008), except where noted. (c) Range of particle diameter over which most pronounced rate-weakening is expected $(1<R<10)$, over the range of slip velocity during stickslip cycles at WIS $\left(90-8000 \mathrm{~m} \mathrm{a}^{-1}\right.$, with $\left.D=10^{-8} \mathrm{~m}^{2} \mathrm{~s}^{-1}\right)$.

were caused by excess pore pressures (Fig. 6a), which have also been measured in subglacial ploughmeter experiments (Rousselot and Fischer, 2005). Rate weakening during ploughing depends on the till hydraulic diffusivity, the speed of ploughing particles, $V_{\mathrm{p}}$, and their diameter, $d$. The dimensionless parameter, $R=V_{p} d / D$, is the ratio of characteristic timescales for diffusion and till compaction downglacier from ploughing particles. Ploughing experiments demonstrate that excess pore pressures increase most dramatically across the range $R=1-10$ (Thomason and Iverson, 2008) (Fig. 6b). Considering ploughing speeds at WIS commensurate with sliding speeds there during a stickslip cycle (90-8000 $\mathrm{m} \mathrm{a}^{-1}$; Sergienko and others, 2009), and again taking $D=10^{-8} \mathrm{~m}^{2} \mathrm{~s}^{-1}$ for the WIS till, indicates that ploughing particles ranging from $\sim 0.04$ to $33 \mathrm{~mm}$ in diameter will result in $R$ values that span part of the range over which rate-weakening is pronounced (Fig. 6c). Clasts in the geologic record that have ploughed through the bed surface span the upper end of this size range, $8-40 \mathrm{~mm}$, with smaller particles accommodated too easily by regelation to plough (Iverson and Hooyer, 2004). The time dependence of healing by pore-pressure diffusion between rapid-slip periods can also be estimated, assuming that during intervening periods slow slip is by bed deformation, so that ploughing speed is zero. Considering a range of particle diameters in an analytical solution for pore-pressure decay immediately adjacent to a driven pile (Randolph and Wroth, 1979) yields a decrease in healing rate with time similar to that inferred at WIS (Fig. 5b) (Winberry and others, 2009).

The conspicuous stick-slip modulated by tidal forcing at WIS does not occur at Kamb and Bindschadler Ice Streams. Flow perturbations caused by tidal forcing propagate more than an order of magnitude more slowly along these ice streams than at WIS, indicating perhaps a pseudo-viscous, delayed response in the basal till there (Bindschadler and others, 2003). If so, till beneath WIS may remain at or near its critical-state porosity, whereas till beneath Kamb and Bindschadler Ice Streams may remain less porous than in its critical state, so that dilatant strengthening is operative. Alternatively, ploughing at WIS keeps it poorly coupled to its bed, in agreement with measurements of bed shear focused within $30 \mathrm{~mm}$ of the glacier sole there but not at Bindschadler Ice Stream where more deformation occurs at depth in the bed (Kamb, 2001). A third explanation is that beneath Kamb and Bindschadler Ice Streams sticky spots are more pervasive than at WIS, and these sticky spots cause rate-strengthening shear resistance (Cuffey and Paterson, 2010). Rate-strengthening would be expected from bed patches that are rigid, owing to till that is absent, frozen or well drained.

\section{TILL CONTINUITY}

How are soft beds sustained? The time-variation in till thickness, $h$, at a location on the bed depends on the supply of debris from sediment sources and outflow by sediment transport:

$$
\frac{\partial h}{\partial t}=\dot{s}_{\mathrm{i}}+\dot{s}_{\mathrm{b}}-\nabla \cdot q_{\mathrm{b}}-\nabla \cdot q_{\mathrm{w}}
$$

where $\dot{s}_{\mathrm{i}}$ is the rate of till deposition from ice (negative for entrainment by ice), $\dot{s}_{\mathrm{b}}$ is the rate of erosion from the underlying rigid bed, and $q_{\mathrm{b}}$ is the flux of till conveyed by bed shear (Cuffey and Paterson, 2010). In addition, a sediment flux, $q_{w}$, will be transported by subglacial water. Where a till layer is present, $\dot{s}_{\mathrm{b}}$ will usually be small, owing to the tendency for zero or small slip velocities at the base of a soft bed that exceeds a few decimeters in thickness. The resulting lack of sediment production will tend to deplete the till layer (Cuffey and Alley, 1996; Alley, 2000). Assuming negligible deposition from ice, and importantly, negligible fluvial transport, a till bed can be sustained, nevertheless, if the bed upstream is not shielded by till and is eroded at a sufficient rate. Cuffey and Paterson (2010) balanced rates of glacial erosion averaged over drainage basins (0.1-10 $\mathrm{mm} \mathrm{a}^{-1}$; Hallet and others, 1996) with the flux of sediment that could be transported by bed deformation. If a thin deforming layer $(0.1 \mathrm{~m})$ was assumed, sediment supplied by erosion balanced that transported by bed deformation for a wide range of till velocity $\left(25-2500 \mathrm{~m} \mathrm{a}^{-1}\right)$ averaged over the deforming-layer thickness.

The elephant in the room is fluvial sediment transport. Alley and others (1997) argued persuasively that, owing to large head gradients and fluctuating water discharges, subglacial channels fed by glacier surface water are the most effective of glacial sediment-transport mechanisms. Till 
layers beneath ice streams without surface water input, such as those of the Siple Coast in Antarctica, are protected from this drainage and likely persist partly for this reason. However, soft beds are also common beneath modern glaciers with ample surface water input during vigorous summer surface melting (e.g. Boulton and Hindmarsh, 1987; Humphrey and others, 1993; Truffer and others, 1999). Some soft beds may be inherently transient and persist largely because glaciers sometimes override thick layers of preexisting unlithified sediment (e.g. Alley, 2000). In addition, however, soft beds may slow their own depletion by helping to control the character of the subglacial hydraulic system.

Water may flow beneath soft-bedded glaciers in a thin zone of enhanced permeability at the bed surface (e.g. Stone and Clarke, 1993), an irregular water layer at the bed surface with ice spanning the largest till particles (e.g. Creyts and Schoof, 2009), shallow channels cut partly into the till bed (Walder and Fowler, 1994; Engelhardt and Kamb, 1997; Ng, 2000), or some combination of these. Regardless of which of these styles of drainage system predominates, bed shear stresses necessary to drive sediment transport by flowing water will be minimized, due to both small flow depths and small hydraulic potential gradients expected for gently sloping glaciers resting on soft beds (e.g. Walder and Fowler, 1994). Soft beds, therefore, tend to suppress deep, rapid subglacial water flows that might otherwise erode them.

The tendency for such drainage systems on soft beds to support low effective pressures (e.g. Walder and Fowler, 1994; Rempel, 2009) may also help sustain soft beds. As noted, measurements at several glaciers indicate that falling or low effective pressures can weaken the ice-till interface preferentially, thereby focusing motion there rather than deeper in the bed. This process will reduce rates of sediment transport by bed deformation. In addition, low effective pressure reduces the tendency for ice to infiltrate the bed by regelation and thereby erode it. Rempel (2008) has recently provided a comprehensive theoretical foundation for this process and finds that depths of regelation infiltration into the bed may be several decimeters to meters, even after accounting for heat production by sliding. Both field observations (Iverson and others, 2007) and laboratory experiments (Iverson and Semmens, 1995) indicate that this process can operate in sediments with till-like grain-size distributions. Resultant fluxes of dense debris in ice, therefore, could be high. However, predicted infiltration depths decrease with decreasing effective pressure, and for tills there is no infiltration below effective pressures of $\sim 10 \mathrm{kPa}$ (Rempel, 2008, 2009). Also, in response to sufficiently rapid basal melting, particles in basal ice will be readily pressed into and hence deposited on a soft bed weakened by low effective pressure (Brown and others, 1987). This lodgment process will not generally occur on a hard bed because such particles, rather than be extruded, remain in ice as basal melting forces ice to flow past them (e.g. Hallet, 1979). Low effective pressure in channels also reduces hydraulic gradients in adjacent subglacial till layers, which will inhibit erosion of channel banks by seepagedriven sapping or mass failures.

\section{CONCLUSIONS}

The critical-state shear resistance of till is insensitive to its deformation rate, with a Coulomb dependence on effective pressure. This finding should hearten glaciologists. Owing to small values of cohesion (Fig. 2b), the simple friction rule, $\tau_{\mathrm{u}} \approx P_{\mathrm{e}} \tan \phi$, allows resistance to glacier slip for a deforming bed to be estimated with greater certainty than for a rigid bed. For a particular value of $P_{\mathrm{e}}$, knowledge of only the critical-state friction angle, which can be either estimated from a till grain-size distribution or measured, is needed for a good estimation of slip resistance. In comparison, hardbedded sliding, with its dependencies on basal ice rheology, bed geometry, ice-bed separation, regelation and debris-bed friction, is restrictively complex.

On the other hand, knowledge of effective pressure and hence of pore-water pressure distributions in the bed is fundamental. Alternatively, water content (or void ratio or porosity) can be used as a surrogate for effective pressure for deformation of a water-saturated till in the critical state (e.g. Tulaczyk and others, 2000b). In either case, the conclusion is the same: determining till shear resistance and associated kinematics of till deformation are problems centered on hydrology. For example, patterns of deformation in a soft bed will be sensitive to the distribution of non-hydrostatic pore pressure associated with pore-water flow. Yet in models that purport to help illuminate patterns of till deformation with depth, pore-water pressure is usually assumed to be hydrostatic (see Hooke, 2005, p. 187, for a review).

Non-hydrostatic pore pressure and associated pore-water flow can also govern feedbacks between deformation and effective pressure. Transient deformation of till that is initially less porous than in its critical state can result in a pseudo-viscous response caused by dilation and resultant pore-pressure reduction. However, this effect may not be common because tills with hydraulic diffusivities sufficiently small to enable dilatant strengthening are also those least likely to depart significantly from their critical-state porosities during effective-pressure transients.

Rapid-slip episodes at WIS require rate-weakening of its basal till and its strengthening (healing) during intervening periods of slow slip. Some tills rate-weaken sufficiently and some fault gouges heal sufficiently rapidly to account for strength variations at WIS, but the relevance of these results to the WIS till is uncertain. The low hydraulic diffusivity of the WIS till indicates that strength variations, if caused by pore-pressure changes either associated or unassociated with basal freezing, must be focused in the uppermost several centimeters of the bed to account for rapid-slip recurrence intervals of $<1$ day. The hypothesis that stick-slip is caused by basal freezing, which strengthens the bed during periods of slow slip by withdrawing water from it, is problematic: till consolidation during water withdrawal would prompt dilatant strengthening during subsequent rapid slip, rather than weakening. Frictional production of water during short periods of rapid slip will likely be too brief to counteract this effect.

Alternatively, ploughing of particles can result in excess pore pressures in adjacent till that are proportional to ploughing speed, causing rate-weakening slip focused within a few centimeters of the bed surface. Pore-pressure diffusion during intervening periods can heal till adjacent to particles that have ploughed and thereby increase slip resistance. Ploughing particles less than a few centimeters in diameter can cause rate-weakening over the range of slip velocity at WIS and sufficient healing during periods of slow slip.

Hydrological feedbacks associated with soft beds may help enhance their growth and inhibit their erosion. Shallow 
and sluggish subglacial water flows that typify soft-bedded glaciers may commonly be insufficient to exceed critical bed shear stresses necessary to transport constituent grains. Moreover, low effective pressures in soft beds inhibit sediment transport processes, including deep bed deformation, entrainment of sediment in ice by regelation infiltration, and seepage-driven erosion of channel banks, while promoting subglacial lodgment of debris from ice.

\section{ACKNOWLEDGEMENTS}

I thank T. Hooyer, P. Moore and J. Thomason for their help studying till behaviour, and the US National Science Foundation for helping to support those studies. An anonymous reviewer made comments that improved the paper.

\section{REFERENCES}

Alley, R.B. 1989. Water-pressure coupling of sliding and bed deformation: II. Velocity-depth profiles. J. Glaciol., 35(119), 119-129.

Alley, R.B. 1991. Deforming-bed origin for southern Laurentide till sheets? J. Glaciol., 37(125), 67-76.

Alley, R.B. 1993. In search of ice-stream sticky spots. J. Glaciol., 39(133), 447-454.

Alley, R.B. 2000. Continuity comes first: recent progress in understanding subglacial deformation. In Maltman, A.J., B. Hubbard and M.J. Hambrey, eds. Deformation of glacial materials. London, Geological Society, 171-179. (Special Publication 176.)

Alley, R.B., D.D. Blankenship, C.R. Bentley and S.T. Rooney. 1986. Deformation of till beneath Ice Stream B, West Antarctica. Nature, 322(6074), 57-59.

Alley, R.B., D.D. Blankenship, C.R. Bentley and S.T. Rooney. 1987. Till beneath Ice Stream B. 3. Till deformation: evidence and implications. J. Geophys. Res., 92(B9), 8921-8929.

Alley, R.B., K.M. Cuffey, E.B. Evenson, J.C. Strasser, D.E. Lawson and G.J. Larson. 1997. How glaciers entrain and transport basal sediment: physical constraints. Quat. Sci. Rev., 16(9), 1017-1038.

Anandakrishnan, S. and R.B. Alley. 1997. Tidal forcing of basal seismicity of Ice Stream C, West Antarctica, observed far inland. J. Geophys. Res., 102(B7), 15,183-15,196.

Bindschadler, R.A., M.A. King, R.B. Alley, S. Anandakrishnan and L. Padman. 2003. Tidally controlled stick-slip discharge of a West Antarctic ice stream. Science, 301(5636), 1087-1089.

Blake, E., G.K.C. Clarke and M.C. Gérin. 1992. Tools for examining subglacial bed deformation. J. Glaciol., 38(130), 388-396.

Blake, E.W., U.H. Fischer and G.K.C. Clarke. 1994. Direct measurement of sliding at the glacier bed. J. Glaciol., 40(136), 595-599.

Blankenship, D.D., C.R. Bentley, S.T. Rooney and R.B. Alley. 1986. Seismic measurements reveal a saturated porous layer beneath an active Antarctic ice stream. Nature, 322(6074), 54-57.

Boulton, G.S. 1970a. On the deposition of subglacial and melt-out tills at the margins of certain Svalbard glaciers. J. Glaciol., 9(56), 231-245.

Boulton, G.S. 1970b. On the origin and transport of englacial debris in Svalbard glaciers. J. Glaciol., 9(56), 213-229.

Boulton, G.S. 1975. Processes and patterns of subglacial sedimentation: a theoretical approach. In Wright, A.E. and F. Moseley, eds. Ice ages: ancient and modern. Liverpool, Seel House Press, $7-42$.

Boulton, G.S. 1976. The origin of glacially fluted surfaces: observations and theory. J. Glaciol., 17(76), 287-309.

Boulton, G.S. 1979. Processes of glacier erosion on different substrata. J. Glaciol., 23(89), 15-38.
Boulton, G.S. 1986. Geophysics: a paradigm shift in glaciology? Nature, 322(6074), 18.

Boulton, G.S. 1996. Theory of glacial erosion, transport and deposition as a consequence of subglacial sediment deformation. J. Glaciol., 42(140), 43-62.

Boulton, G.S. and D.L. Dent. 1974. The nature and rates of postdepositional changes in recently deposited till from south-east Iceland. Geogr. Ann., 56A(3-4), 121-134.

Boulton, G.S. and R.C.A. Hindmarsh. 1987. Sediment deformation beneath glaciers: rheology and geological consequences. J. Geophys. Res., 92(B9), 9059-9082.

Boulton, G.S. and A.S. Jones. 1979. Stability of temperate ice caps and ice sheets resting on beds of deformable sediment. J. Glaciol., 24(90), 29-43.

Boulton, G.S. and M.A. Paul. 1976. The influence of genetic processes on some geotechnical properties of glacial tills. Q. J. Eng. Geol., 9(3), 159-194.

Boulton, G.S., D.L. Dent and E.M. Morris. 1974. Subglacial shearing and crushing, and the role of water pressures in tills from south-east Iceland. Geogr. Ann., 56A(3-4), 135-145.

Boulton, G.S., K.E. Dobbie and S. Zatsepin. 2001. Sediment deformation beneath glaciers and its coupling to the subglacial hydraulic system. Quat. Int., 86(1), 3-28.

Brown, N.E., B. Hallet and D.B. Booth. 1987. Rapid soft bed sliding of the Puget glacial lobe. J. Geophys. Res., 92(B9), 8985-8997.

Carter, J.P., M.F. Randolph and C.P. Wroth. 1979. Stress and pore pressure changes in clay during and after the expansion of a cylindrical cavity. Int. J. Num. Anal. Meth. Geomech., 3(4), 305-32

Christoffersen, P. and S. Tulaczyk. 2003. Thermodynamics of basal freeze-on: predicting basal and subglacial signatures of stopped ice streams and interstream ridges. Ann. Glaciol., 36, 233-243.

Clark, P.U. 1987. Subglacial sediment dispersal and till composition. J. Geol., 95(4), 527-541.

Clark, P.U. 1992. Surface form of the southern Laurentide ice sheet and its implications to ice-sheet dynamics. Geol. Soc. Am. Bull., 104(5), 595-605.

Clark, P.U. 1994. Unstable behavior of the Laurentide ice sheet over deforming sediment and its implications for climate change. Quat. Res., 41(1), 19-25.

Clark, P.U. and A.K. Hansel. 1989. Clast ploughing, lodgement and glacier sliding over a soft glacier bed. Boreas, 18(3), 201-207.

Clarke, G.K.C. 1987a. Fast glacier flow: ice streams, surging and tidewater glaciers. J. Geophys. Res., 92(B9), 8835-8841.

Clarke, G.K.C. 1987b. Subglacial till: a physical framework for its properties and processes. J. Geophys. Res., 92(B9), 9023-9036.

Clarke, G.K.C. 2005. Subglacial processes. Annu. Rev. Earth Planet. Sci., 33, 247-276.

Creyts, T.T. and C.G. Schoof. 2009. Drainage through subglacial water sheets. J. Geophys. Res., 114(F4), F04008. (10.1029/ 2008JF001215.)

Cuffey, K. and R.B. Alley. 1996. Is erosion by deforming subglacial sediments significant? (Toward till continuity). Ann. Glaciol., 22, $17-24$.

Cuffey, K.M. and W.S.B. Paterson. 2010. The physics of glaciers. Fourth edition. Oxford, Butterworth-Heinemann.

Dyson, J.L. 1952. Ice-ridged moraines and their relation to glaciers. Am. J. Sci., 250(3), 204-211.

Ehlers, J. and H.J. Stephan. 1979. Forms at the base of till strata as indicators of ice movement. J. Glaciol., 22(87), 345-355.

Engelhardt, H. and B. Kamb. 1997. Basal hydraulic system of a West Antarctic ice stream: constraints from borehole observations. J. Glaciol., 43(144), 207-230.

Engelhardt, H. and B. Kamb. 1998. Basal sliding of Ice Stream B, West Antarctica. J. Glaciol., 44(147), 223-230.

Engelhardt, H., N. Humphrey, B. Kamb and M. Fahnestock. 1990. Physical conditions at the base of a fast moving Antarctic ice stream. Science, 248(4951), 57-59.

Fischer, U.H. and G.K.C. Clarke. 1997. Stick-slip sliding behaviour at the base of a glacier. Ann. Glaciol., 24, 390-396. 
Fowler, A.C. 1979. A mathematical approach to the theory of glacier sliding. J. Glaciol., 23(89), 131-141.

Fowler, A.C. 2003. On the rheology of till. Ann. Glaciol., 37, $55-59$.

Freeze, R.A. and J.A. Cherry. 1979. Groundwater. Englewood Cliffs, NJ, Prentice Hall.

Hallet, B. 1979. A theoretical model of glacial abrasion. J. Glaciol., 23(89), 39-50.

Hallet, B., L.E. Hunter and J. Bogen. 1996. Rates of erosion and sediment evacuation by glaciers: a review of field data and their implications. Global Planet. Change, 12(1-4), 213-235.

Hindmarsh, R. 1997. Deforming beds: viscous and plastic scales of deformation. Quat. Sci. Rev., 16(9), 1039-1056.

Hodge, S.M. 1979. Direct measurement of basal water pressures: progress and problems. J. Glaciol., 23(89), 309-319.

Hooke, R.LeB. 2005. Principles of glacier mechanics. Second edition. Cambridge, etc., Cambridge University Press.

Hooke, R.LeB., B. Hanson, N.R. Iverson, P. Jansson and U.H. Fischer. 1997. Rheology of till beneath Storglaciären, Sweden. J. Glaciol., 43(143), 172-179.

Hoppe, G. 1952. Hummocky moraine regions, with special reference to the interior of Norrbotten. Geogr. Ann., 34(1/2), $1-72$.

Humphrey, N., B. Kamb, M. Fahnestock and H. Engelhardt. 1993. Characteristics of the bed of the lower Columbia Glacier, Alaska. J. Geophys. Res., 98(B1), 837-846.

Iverson, N.R. 1999. Coupling between a glacier and a soft bed: II. Model results. J. Glaciol., 45(149), 41-53.

Iverson, R.M. 2003. How should mathematical models of geomorphic processes be judged? In Wilcock, P.R. and R.M. Iverson, eds. Prediction in geomorphology. Washington, DC, American Geophysical Union, 83-94. (AGU Geophysical Monograph 135.)

Iverson, N.R. and T.S. Hooyer. 2004. Estimating the sliding velocity of a Pleistocene ice sheet from plowing structures in the geologic record. J. Geophys. Res., 109(F4), F04006. (10.1029/ 2004JF000132.)

Iverson, N.R. and D.J. Semmens. 1995. Intrusion of ice into porous media by regelation: a mechanism of sediment entrainment by glaciers. J. Geophys. Res., 100(B7), 10,219-10,230.

Iverson, N.R., B. Hanson, R.LeB. Hooke and P. Jansson. 1995. Flow mechanism of glaciers on soft beds. Science, 267(5194), 80-81.

Iverson, R.M., M.E. Reid and R.G. LaHusen. 1997. Debris-flow mobilization from landslides. Annu. Rev. Earth Planet. Sci., 25, 85-138

Iverson, N.R., T.S. Hooyer and R.W. Baker. 1998. Ring-shear studies of till deformation: Coulomb-plastic behavior and distributed strain in glacier beds. J. Glaciol., 44(148), 634-642.

Iverson, N.R., R.W. Baker, R.LeB. Hooke, B. Hanson and P. Jansson. 1999. Coupling between a glacier and a soft bed: I. A relation between effective pressure and local shear stress determined from till elasticity. J. Glaciol., 45(149), 31-40.

Iverson, N.R. and 7 others. 2007. Soft-bed experiments beneath Engabreen, Norway: regelation infiltration, basal slip and bed deformation. J. Glaciol., 53(182), 323-340.

Joughin, I., S. Tulaczyk, D. MacAyeal and H. Engelhardt. 2004. Melting and freezing beneath the Ross ice streams, Antarctica. J. Glaciol., 50(168), 96-108.

Kamb, B. 1970. Sliding motion of glaciers: theory and observation. Rev. Geophys. Space Phys., 8(4), 673-728.

Kamb, B. 1991. Rheological nonlinearity and flow instability in the deforming bed mechanism of ice stream motion. J. Geophys. Res., 96(B10), 16,585-16,595.

Kamb, B. 2001. Basal zone of the West Antarctic ice streams and its role in lubrication of their rapid motion. In Alley, R.B. and R.A. Bindschadler, eds. The West Antarctic ice sheet: behavior and environment. Washington, DC, American Geophysical Union, 157-199. (Antarctic Research Series 77.)

Kavanaugh, J.L. and G.K.C. Clarke. 2006. Discrimination of the flow law for subglacial sediment using in situ measurements and an interpretation model. J. Geophys. Res., 111(F1), F01002. (10.1029/2005JF000346.)

Lambe, T.W. and R.V. Whitman. 1969. Soil mechanics. New York, etc., John Wiley and Sons.

Lliboutry, L. 1979. Local friction laws for glaciers: a critical review and new openings. J. Glaciol., 23(89), 67-95.

MacAyeal, D.R. 1989. Large-scale ice flow over a viscous basal sediment: theory and application to Ice Stream B, Antarctica. J. Geophys. Res., 94(B4), 4071-4087.

MacAyeal, D.R. 1992. Irregular oscillations of the West Antarctic ice sheet. Nature, 359(6390), 29-32.

MacAyeal, D.R., R.A. Bindschadler and T.A. Scambos. 1995. Basal friction of Ice Stream E, West Antarctica. J. Glaciol., 41(138), 247-262.

MacClintock, P. and A. Dreimanis. 1964. Orientation of till fabric by an overriding glacier in the Saint Lawrence Valley. Am. J. Sci., 262(1), 133-142.

Marone, C. 1998a. The effect of loading rate on static friction and the rate of fault healing during the earthquake cycle. Nature, 391(6662), 69-72.

Marone, C. 1998b. Laboratory-derived friction laws and their application to seismic faulting. Annu. Rev. Earth Planet. Sci., 26, 643-696.

Marone, C. and B. Kilgore. 1993. Scaling of the critical slip distance for seismic faulting with shear strain in fault zones. Nature, 362(6421), 618-621.

McGee, W.J. 1894. Glacial canons. J. Geol., 2(4), 350-364.

Moore, P.L. 2002. A laboratory study of dilatant hardening: a mechanism for slow shear of granular materials. (MS thesis, lowa State University.)

Moore, P.L. and N.R. Iverson. 2002. Slow episodic shear of granular materials regulated by dilatant strengthening. Geology, 30(9), 843-846.

Moran, S.R. 1971. Glaciotectonic structures in drift. In Goldthwait, R.P., ed. Till: a symposium. Columbus, $\mathrm{OH}$, Ohio State University Press, 127-148.

Murray, T. 1997. Assessing the paradigm shift: deformable glacier beds. Quat. Sci. Rev., 16(9), 995-1016.

$\mathrm{Ng}$, F.S.L. 2000. Canals under sediment-based ice sheets. Ann. Glaciol., 30, 146-152.

Nye, J.F. 1970. Glacier sliding without cavitation in a linear viscous approximation. Proc. R. Soc. London, Ser. A, 315(1522), 381-403.

Price, S.F., R.A. Bindschadler, C.L. Hulbe and D.D. Blankenship. 2002. Force balance along an inland tributary and onset to Ice Stream D, West Antarctica. J. Glaciol., 48(160), 20-30.

Randolph, M.F. and C.P. Wroth. 1979. An analytical solution for the consolidation around a driven pile. Int. J. Num. Anal. Meth. Geomech., 3(3), 217-229.

Rathbun, A.P., C. Marone, R.B. Alley and S. Anandakrishnan. 2008. Laboratory study of the frictional rheology of sheared till. J. Geophys. Res., 113(F2), F02020. (10.1029/2007JF000815.)

Raymond, C.F., K.A. Echelmeyer, I.M. Whillans and C.S.M. Doake. 2001. Ice stream shear margins. In The West Antarctic ice sheet: behavior and environment. Washington, DC, American Geophysical Union, 137-155. (Antarctic Research Series 77.)

Rempel, A.W. 2008. A theory for ice-till interactions and sediment entrainment beneath glaciers. J. Geophys. Res., 113(F1), F01013. (10.1029/2007JF000870.)

Rempel, A.W. 2009. Effective stress profiles and seepage flows beneath glaciers and ice sheets. J. Glaciol., 55(191), 431-443.

Reynolds, O. 1885. On the dilatancy of media composed of rigid particles in contact, with experimental illustrations. Philos. Mag., 20(127), 469-481.

Rousselot, M. and U.H. Fischer. 2005. Evidence for excess porewater pressure generated in subglacial sediment: implications for clast ploughing. Geophys. Res. Lett., 32(11), L11501. (10.1029/2005GL022642.)

Rousselot, M. and U.H. Fischer. 2007. A laboratory study of ploughing. J. Glaciol., 53(181), 225-231. 
Sane, S.M., C.S. Desai, J.W. Jenson, D.N. Contractor, A.E. Carlson and P.U. Clark. 2008. Disturbed state constitutive modeling of two Pleistocene tills. Quat. Sci. Rev., 27(3-4), 267-283.

Savage, S.B. 1998. Modeling and granular material boundary value problems. In Herrman, H.J., J.-P. Hovi and S. Luding, eds. Physics of dry granular media. Proceedings of the NATO Advanced Study Institute, Cargèse, France, September 15-26, 1997. Dordrecht, etc., Kluwer Academic, 25-96. (NATO ASI Series E, Applied Sciences 350.)

Schofield, A.N. and C.P. Wroth. 1968. Critical state soil mechanics. London, McGraw Hill.

Scholz, C.H. 2002. The mechanics of earthquakes and faulting. Second edition. Cambridge, etc., Cambridge University Press.

Segall, P., A.M. Rubin, A.M. Bradley and J.R. Rice. 2010. Dilatant strengthening as a mechanism for slow slip events. J. Geophys. Res., 115(B12), B12305. (10.1029/2010JB007449.)

Sergienko, O., D.R. MacAyeal and R.A. Bindschadler. 2009. Stickslip behavior of ice streams: modeling investigations. Ann. Glaciol., 50(52), 87-94.

Shaw, J. 1982. Melt-out till in the Edmonton area, Alberta, Canada. Can. J. Earth Sci., 19(8), 1548-1569.

Shaw, J. 1987. Glacial sedimentary processes and environmental reconstruction based on lithofacies. Sedimentology, 34(1), 103-116.

Slater, G. 1926. Glacial tectonics as reflected in disturbed drift deposits. Proc. Geol. Assoc., 37, 392-400.

Stokes, C.R., C.D. Clark, O.B. Lian and S. Tulaczyk. 2007. Ice stream sticky spots: a review of their identification and influence beneath contemporary and palaeo-ice streams. Earth-Sci. Rev., 81(3-4), 217-249.

Stone, D.B. and G.K.C. Clarke. 1993. Estimation of subglacial hydraulic properties from induced changes in basal water pressure: a theoretical framework for borehole-response tests. J. Glaciol., 39(132), 327-340.

Terzaghi, K. 1943. Theoretical soil mechanics. New York, John Wiley and Sons.

Thomason, J.F. and N.R. Iverson. 2008. A laboratory study of particle ploughing and pore-pressure feedback: a velocityweakening mechanism for soft glacier beds. J. Glaciol., 54(184), 169-181.

Tika, T.E., P.R. Vaughan and L.J. Lemos. 1996. Fast shearing of preexisting shear zones in soil. Géotechnique, 46(2), 197-233.
Truffer, M. and W.D. Harrison. 2006. In situ measurements of till deformation and water pressure. J. Glaciol., 52(177), 175-182.

Truffer, M., R.J. Motyka, W.D. Harrison, K.A. Echelmeyer, B. Fisk and S. Tulaczyk. 1999. Subglacial drilling at Black Rapids Glacier, Alaska, U.S.A.: drilling method and sample descriptions. J. Glaciol., 45(151), 495-505.

Truffer, M., K.A. Echelmeyer and W.D. Harrison. 2001. Implications of till deformation on glacier dynamics. J. Glaciol., 47(156), 123-134.

Tulaczyk, S. 1999. Ice sliding over weak, fine-grained tills: dependence of ice-till interactions on till granulometry. In Mickelson, D.M. and J.W. Attig, eds. Glacial processes: past and present. Boulder, CO, Geological Society of America, 159-177. (Special Paper 337.)

Tulaczyk, S. 2006. Scale independence of till rheology. J. Glaciol., 52(178), 377-380.

Tulaczyk, S.M., B. Kamb and H.F. Engelhardt. 2000a. Basal mechanics of Ice Stream B, West Antarctica. I. Till mechanics. J. Geophys. Res., 105(B1), 463-481.

Tulaczyk, S.M., B. Kamb and H.F. Engelhardt. 2000b. Basal mechanics of Ice Stream B, West Antarctica. II. Undrainedplastic-bed model. J. Geophys. Res., 105(B1), 483-494.

Walder, J.S. and A. Fowler. 1994. Channelized subglacial drainage over a deformable bed. J. Glaciol., 40(134), 3-15.

Weertman, J. 1979. The unsolved general glacier sliding problem. J. Glaciol., 23(89), 97-115.

Westgate, J.A. 1968. Linear sole markings in Pleistocene till. Geol. Mag., 105(6), 501-505.

Whillans, I.M. and C.J. van der Veen. 1997. The role of lateral drag in the dynamics of Ice Stream B, Antarctica. J. Glaciol., 43(144), 231-237

Wiens, D.A., S. Anandakrishnan, J.P. Winberry and M.A. King. 2008. Simultaneous teleseismic and geodetic observations of the stick-slip motion of an Antarctic ice stream. Nature, 453(7196), 770-774.

Winberry, J.P., S. Anandakrishnan, R.B. Alley, R.A. Bindschadler and M.A. King. 2009. Basal mechanics of ice streams: insights from the stick-slip motion of Whillans Ice Stream, West Antarctica. J. Geophys. Res., 114(F1), F01016. (10.1029/ 2008JF001035.)

Wood, D.M. 1990. Soil behaviour and critical state soil mechanics. Cambridge, Cambridge University Press. 